\title{
PURSUING A SOCIAL DEVELOPMENT AGENDA IN THE CONTEXT OF GLOBALISATION: A SOUTH AFRICAN PERSPECTIVE
}

\section{Jean Triegaardt}

\section{INTRODUCTION}

After 1994 the South African government had to contend with the consequences of the forces of globalisation in addition to meeting the challenges of nation building. The new democratic government inherited a fragile economy burdened with large debt, slow economic growth, increasing unemployment rates and unacceptable levels of poverty (Padayachee, 2005:22). Constitutional imperatives called for a just and equitable society, a fundamental principle that formed the basis for all future policies and legislation (RSA, 1996).

Fourteen years after the first democratic election many citizens continue to feel the effects of rising unemployment, inequality and sustained poverty. There are writers who contend that the headcount of poverty has decreased (Van der Berg, Burger, Burger, Louw \& Yu, 2005), but critics maintain that there has been under-reporting in statistics and that poverty has not decreased. The Gini-coefficient suggests that South Africa has a high rate of inequality and has been compared to Brazil in this respect. Socio-economic policies have been targeted towards achieving macro-economic stability, increasing access to basic services, especially water, electricity and health, and social security (Fedderke, 2006; Van der Berg et al., 2005).

The purpose of this paper is to analyse policies with respect to social development initiatives, the gains that have been achieved and the challenges that remain for poverty-stricken South Africans within a globalised environment.

\section{CONCEPTUALISATION OF GLOBALISATION AND SOCIAL DEVELOPMENT}

Globalisation has increased in complexity over the past decades because of the growth in technology and trade; travel between countries has become more rapid as a result of more sophisticated and improved engineering; people migrate across national borders for a range of reasons; and there is a desire (albeit among a few wealthy individuals and companies) to accrue wealth beyond national borders. Therefore, globalisation may be viewed as a process of the exchange of ideas, culture, technology, trade and industry, communication, and the migration of people and capital across national boundaries. Midgley defines globalisation as:

A process of global integration in which diverse peoples, economies, cultures, and political processes are increasingly subjected to international influences and people are made aware of the role of these influences in their everyday lives. (Midgley, 1997:21)

Many writers have written about social development over several decades (Gray, 1997; Lombard, 1996; Midgley, 1995; Paiva, 1997; Patel, 2005). The often-quoted definition by Midgley (1995:250) on social development is that it is ".... process of planned social change designed to promote the well-being of the population as a whole in conjunction with a dynamic process of economic development". As one analyses social development and its progress in the $21^{\text {st }}$ century, and given the political commitment to its implementation, it certainly does have policy implications and consequences for a society's well-being. Social welfare systems have been informed by a complex range of historical, cultural, political, social and economic institutions and processes. Social welfare policies and programmes serve to promote social inclusion, social cohesion and integration in a society (Patel, 2005:19). South Africa has 
introduced a social development perspective through the creation of its White Paper for Social Welfare (1997). The ultimate goal of social welfare is to improve the well-being and quality of life, particularly of poor and marginalised people in South Africa. When social goals are combined with economic objectives by investing in human capital, the well-being of all individuals in society can be achieved.

\section{BACKGROUND ON SOUTH AFRICA}

Once democracy had been established in South Africa, the Constitution was formulated to provide safeguards for its citizens. These included a common South African citizenship, universal adult suffrage, human rights, a multiparty democracy, a free press and judicial review of government. The Bill of Rights upholds civil and political rights, language and cultural rights, children's rights, the right to social security, education and health care, while food, water and housing are among the social and economic rights. The right to equality is designed to protect or advance persons or categories of persons who were disadvantaged or discriminated against in the past on grounds of, among other things, race, gender, age, disability or ethnic or social origin. Section 36 of the Constitution makes provision for the limitation of these rights to the extent that their implementation is reasonably practicable and justifiable in an open and democratic society. The right to access social assistance, health care, food and water is protected, but the Bill of Rights states that this right is subject to available resources and that the state should demonstrate that it is taking reasonable steps to realise this right progressively.

To date, South Africa as an emerging democracy has had to grapple with the enormous challenges of debt incurred by the previous apartheid system, unemployment, poverty and rising inequality. In the mid-1990s, the government introduced an orthodox macro-economic policy called Growth, Employment and Redistribution (GEAR) (1996). This policy focused on the improvement of economic growth, reduction of debt, job creation and liberalising trade and industry. During the GEAR era, economic growth was low and employment rates decreased in sectors such as mining, manufacturing and construction (Padayachee, 2005:558). Seekings and Nattrass (2005:349) note that, out of the four major components of the GEAR strategy, only the reduced budget deficit and trade liberalisation had been implemented by 2004; the other two labour market reforms and privatisation - were not implemented. Critics of the GEAR macroeconomic policy suggest that it was a neo-liberal policy with more of a focus on promoting economic growth, liberalising trade and reducing debt rather than on job creation and welfare reforms.

Globalisation does pose challenges in terms of changing labour markets and information and technological advances. Changes have occurred in the nature of employment and full-time permanent employment. Employment has increased in sectors such as casualised labour, informal employment and part-time, temporary employment. The consequences of this for national policies are that the government has to contend with job insecurity, labour unrest, rising inequality and poverty, and increasing crime. Formal sector employment in South Africa has declined. Work is being restructured. Labour is more casualised without benefits. Recently (2008) Woolworths workers went on strike because as contract workers they were not allowed to belong to a union. Eventually affiliation to a union was agreed to by management. In 1995, $50 \%$ of GDP comprised the wage economy; the wage share declined to $45 \%$ relative to the profit share in 2005 (Adelzadeh, 2006). 
At present the unemployment figures are in the double digits, with about 8 million people being unemployed (by the expanded definition of unemployment) (STATSSA, 2005). The expanded definition includes people who have given up seeking employment. Just under half of the population of 47 million people are poverty stricken (Adelzadeh, 2006), and inequality is increasing within race groups, but not between race groups (Seekings \& Nattrass, 2005). This information on poverty is confirmed by the UNDP, which suggests that about $50 \%$ of the country's population falls below the national poverty line (UNDP, 2003:70). Income (consumption) inequality can be measured in different ways. Two of these are selected for discussion, namely, the Gini-coefficient and the Human Development Index (HDI). Out of 177 countries ranked by the UNDP, South Africa was placed at number 121 with an HDI of .653 (UNDP, 2006). The HDI is a measure of a country's economic and social well-being. It is a composite index of three factors: life expectancy, educational attainment and income. The South African HDI showed a gradual improvement until 1995, but declined after that. The Gini-coefficient measures the distribution of income/consumption (or assets such as wealth, land or schooling). According to the Gini-coefficient, inequality in South Africa was ranked as the fifth highest in the world (Taylor, 2002:16). The proportion of poverty increased during the period 1993-2000, and this may be attributed to sluggish economic growth and poor labour market prospects (Van der Berg et al., 2005:17). More recently, these writers contend that the headcount of poverty has decreased and that poverty was less in 2004 than in 1993, 1995 or 2000. Poverty headcount numbers first rose and then declined as progress in combating poverty started making headway against population growth (Van der Berg et al., 2005).

The gender dimensions of poverty and unemployment reveal similar patterns. Unemployment is higher for women than men. Black African women have the highest rate of unemployment at $37,1 \%$. The unemployment rate for men was $22,6 \%$, in contrast to women $(31,7 \%)$ in 2005 using the narrow definition of unemployment (STATSSA, 2005:iv). Research revealed that women are disadvantaged in the labour market (Stevens, 2003). They are more likely to be unemployed, or to be in poorly remunerated work. Women are dominant in the informal sector. Seidman-Makgetla (2004) observes that black women are still likely to be unemployed, to be paid less than men when employed, and to perform unpaid labour. Many of the poor are single female heads of households. In 1995, the poverty rate for female heads of households was $60 \%$, which was double that of male-headed households, and this was linked to the concentration of female-headed households in rural areas (Beall, Gelb \& Hassim, 2005:682). Rural households are worse off than urban households with respect to access to transport, basic services and amenities. Rural households accounted for $62 \%$ of all poor households in 1996, but five years later this had declined to 56\% (Bhorat \& Kanbur, 2006:4). This could be indicative of the fact that the process of increasing migration will reshape the spatial nature of poverty.

People with disabilities experience various barriers in trying to access the labour market, education and access to basic services such as transport. All these play a role in contributing to poverty. Therefore, disability has economic consequences and is closely related to poverty because it makes households more vulnerable to poverty and poverty-creating shocks (Taylor, 2002:102, 103). In 2002/2003, out of 12 million people who were economically inactive, 1,2 million people were people with disabilities. A large proportion of people with disabilities are in the lowest income households with the lowest education levels (CASE, 1998). Low educational levels exacerbate unemployment among people with disabilities. There is poor integration into the workplace, for example, a lack of transport that is disability friendly (Leshilo, 2004; DBSA, 2005a). 
HIV/AIDS poses one of the most serious health problems in South Africa and will continue to do so in future. The number of people with HIV/AIDS was estimated at 5,54 million in 2004 (Department of Health, 2005:16). Women are particularly vulnerable, with more women than men being infected. HIV infection is highest amongst women between the ages of 20-29 years (Vass, 2006).

\section{SOCIAL DEVELOPMENT INITIATIVES}

In the process of transformation and grappling with a new democracy, the Mandela-led government in 1994 had to demonstrate its ability to effectively manage the national budget by maintaining economic and financial stability, while contributing to social spending for the poor. The budget became more redistributive after 1994 with the introduction of the Reconstruction and Development Programme (RDP). Within the context of an emerging democracy, the South African government was committed to making provision for the poor and marginalised through its safety-net system of social grants. At the same time it had to be prudent about managing the fiscus, reducing debt and promoting economic growth. In 2005, there was US\$25,9 billion in reserves, the debt ratio was $26 \%$ of GDP, and economic growth was 5\% (Budget Speech, 2007).

Social security has been the fastest growing category of government expenditure since 2001. About 12 million South Africans received social grants in 2008. Social security forms 3,5\% of GDP and amounts to more than R70 billion a year (Budget speech, 2007). Social grants provide more than half of the income of the poorest $20 \%$ of households. Households which receive social grants tend to spend this income on basic needs such as food, fuel, housing and household operations (Department of Social Development, 2006).

Social grants have played a crucial role in poverty reduction and promoting social development. They have reached deep into rural areas, support extended households and are gender sensitive. Research has demonstrated that social pensions contribute significantly to supporting impoverished, rural and female single-headed households (Ardington \& Lund, 1995; Case \& Deaton, 1998; Moller \& Sotshongaye, 1996). Without the contribution of social pensions, poor people, particularly in rural areas, will simply not survive. A study by a group of researchers (Samson, Lee, Ndlebe, MacQuene, Van Niekerk, Gandhi, Harigaya \& Abrahams, 2004) reveals that South Africa's system of social grants successfully reduces poverty, regardless of which methodology is used to quantify the impact measure or identify the poverty line.

The Child Support Grant (CSG) is an institutionalised social grant in South Africa and its benefits are acknowledged. This important grant was introduced in April 1998. It is paid to the primary caregiver and supports impoverished children from 0-14 years. Currently a committee is looking at the feasibility of extending the grant to poor children up to 18 years. Research findings revealed that the CSG has had a significant impact on poor children and povertystricken families. The CSG is used mainly for food, clothes and education (CASE, 2000:43). The Samson et al. study (2004) showed that the greatest poverty-reducing potential lies with the progressive extension of the CSG. The extension to age 14 years yields a $22 \%$ poverty-gap reduction, while the extension to age 18 years reduces the poverty gap by $28,3 \%$. Combining the higher CSG extended to age 14 years with the full take-up rate of the Old Age Pension and the Disability Grant yields a reduction in the total rand poverty gap of 29\% (Samson et al., 2004:2). 
In conjunction with the CSG being paid as a cash transfer to the primary caregiver of the child, the safety net also includes free health care for children under six years and feeding programmes for children. The purpose of the Integrated Nutrition Programme is to provide an inter-sectoral and coordinated programme for nutritional deficiencies among women and children, through health and community-based nutrition services.

Disability grants have increased significantly from 60000 in 2000 to 1,3 million in 2004 (Nattrass, 2006). This growth was facilitated partly by institutional changes in the grantawarding process that adopted a wider interpretation of disability and is increasingly used as a poverty-relief strategy (CASE, 2005). The growth is attributed to increases in the number of people who are HIV positive and who now qualify for the grant.

Gender equality has been provided for in the Constitution, policy documents and the formal institutions of the state. Albertyn (2003:604) states that: “...by 2000, women in South Africa enjoyed unprecedented political and legal equality in the form of political participation and entrenched human and legal rights".

Reforms have been introduced into the unemployment insurance policy. The purpose of unemployment insurance is to safeguard the individual from financial catastrophe during periods of involuntary short-term unemployment (Triegaardt \& Patel, 2005:137). In 2003, the government extended its safety net by making provision for domestic workers in the statutory unemployment insurance scheme. Van der Berg and Bredenkamp (2002) have suggested that the reform of unemployment insurance has made the system more progressive in that lowincome workers benefit more than other categories, and benefits are paid up to $58 \%$ of prior earnings. In the 2007 Budget Speech, the Minister of Finance proposed that a basic saving and social protection system be put in place for the needs of low-income employees. Therefore, a mandatory earnings-related social security scheme will be provided with improved unemployment insurance, disability and death benefits, which will target the income needs of dependants and a standard retirement savings arrangement. In addition, to offset the cost of social security tax for low-income workers and to lower the cost of creating employment, a further proposal to introduce a wage subsidy for those whose earnings fall below the income tax threshold will be submitted. More work is required on these proposals, but clearly the plans are ambitious, with the intention of building a safety net for low-income workers.

The Expanded Public Works Programme (EPWP) was introduced in 2004 as a national priority public works programme with the purpose of creating jobs for the unemployed, utilising labour-intensive methods rather than capital-based technologies. The aim of the programme is to create opportunities for the unemployed to engage in productive work and obtain skills that should be sustainable. The EPWP was created with the purpose of advancing job creation, infrastructure development and service delivery, training and skills development (DBSA, 2005b:30). Most of the jobs that have been created are in construction. Since its inception 300000 jobs have been created, the majority of which are in rural areas, and mostly for women (Budget Speech, 2007). On a practical level, the idea of EPWP is to improve unemployed people's prospects by creating learnerships, developing life skills and providing on-the-job training. The targets which are set for the EPWP programme with respect to people with disabilities, are that 20000 should be employed by 2009.

A National Strategic Plan for 2007-2011 has been finalised to deal with the challenge of HIV and AIDS (Speech for the Acting Minister of Health, 2007:3). This process was a collaborative initiative between government and civil society. The objective of this strategic plan, that is, 
HIV prevention through voluntary testing and counselling (VCT), is to cut new HIV infections by $50 \%$ and bring treatment and support to at least $80 \%$ of HIV positive people by 2011 . VCT is essential for prevention and serves as an entry point to the continuum of treatment, care and support, in addition to strengthening partnerships between the public and private sectors in the delivery of HIV and AIDS care.

\section{CHALLENGES}

The challenges facing South Africa are multifaceted but in the main they are rising inequality, unemployment, crime and the HIV/AIDS pandemic. The government has attempted to raise standards of living for the poor by combining a commitment to economic development with social policies that specifically address and target the problem of poverty. Seekings and Nattrass (2005:336) note the following:

Overall, inequality widened because of the deepening unemployment crisis. Moreover, rapidly changing patterns of mortality and morbidity due to AIDS meant many already poor households were pushed deeper into poverty, and many poor people experienced poor health and died young. People from disadvantaged backgrounds were more vulnerable to the shocks of unemployment and ill health and were poorly placed to take advantage of the opportunities that were opening at the top end of the income distribution.

Inequality is increasing as a result of the unemployment crisis. For the period 1996 to 2006 there was a slight rise in inequality in South Africa as a whole (the Gini-coefficient increased from 0,60 to 0,64$)$. Within race groups, inequalities increased among black South Africans from 0,53 to 0,64; for coloureds from 0,48 to 0,56; for Indian South Africans from 0,47 to 0,50; and for white people it declined slightly from 0,45 to 0,44 (DBSA, 2008; SAIRR, 2005). Research has demonstrated that extreme inequality can be detrimental to economic growth, social stability and development.

South African unemployment is in the main a structural and not a cyclical problem, and thus the policy response needs to address the type of unemployment which prevails in the labour market. There is more demand for skilled labour, which is also reflected in global trends, but the demand for unskilled labour from the formal sector is decreasing. This decrease is largely attributed to structural changes in the economy, resulting from a decline in the importance of the primary sector, technological changes, liberalisation and entry into the global economy (McCord, 2004:2). The consequence of these structural shifts is that the number of labour market entrants exceeds the number of new jobs, resulting in a rapid increase in unskilled unemployment. Most of the unemployed are in the category of unskilled labour.

Intrinsic to all these challenges is the fact that women and children are the most vulnerable. In spite of the gains that have been made with respect to gender equality, critics have expressed concerns that the redistribution of resources and power has not shifted the structural forces with respect to the oppression of women. Inclusion has rather meant an avenue for reinforcing elite women's access to the formal political system, while not (as yet) translating clearly into policies that address the needs of poor women (Hassim, 2006:364).

\section{CONCLUSION}

Despite the many challenges, the government is committed to pursuing development initiatives in trying to address the plight of the poor. Research has demonstrated that social grants have made a distinctive difference to poverty-stricken households. The empirical evidence has 
confirmed that people in households receiving grants have increased their labour-force participation and employment rates faster than those who live in households that do not receive social grants (Samson et al., 2004:4). This evidence confirms the position that South Africa's social security system is a social investment that contributes positively to development. In addition to reducing poverty, there are other developmental outcomes to the social grants, because the facilitation of employment in turn provides access to resources that promote improved education, nutrition, health and other outcomes. Social security, complemented by a range of social welfare and development programmes, is a social and economic investment that contributes significantly towards reducing poverty and to enhanced human capabilities.

The government's approach has been to expand the safety net for children and to combine this with a productivist/investment approach, which includes strategies to accelerate economic growth, employment creation through expanding public works, national youth service programmes, small business development, and skills development strategies. The full impact of all these strategies has not been assessed.

South Africa has to contend with being a player in the global economy and thus is subjected to the pressures of trade and the labour market, and weighing national considerations and priorities against international pressures. Clearly national considerations are crucial to the wellbeing of all citizens and ensuring macro stability. South Africa's economic growth was improving until recently. The challenge is to create conditions which are conducive to supporting and creating opportunities for improving labour market conditions amidst the pressures of a globalised world. As Amartya Sen (1999:3) notes:

Development requires the removal of major sources of unfreedom; poverty as well as tyranny, poor economic opportunities as well as systematic social deprivation, neglect of public facilities as well as intolerance or over-activity of repressive states.

\section{REFERENCES}

ADELZADEH, A. 2006. Overcoming unemployment. Strategies for giving the effect to the right to work. Conference on unemployment. Alternate Information Development Centre. Cape Town: District Six Museum. 12-15 June.

ALBERTYN, C. 2003. Contesting democracy: HIV/AIDS and the achievement of gender equality in South Africa. Feminist Studies, 29(3):595-615.

ARDINGTON, E. \& LUND, F. 1995. Pensions and development: social security as complementary to programmes of reconstruction and development. Development Southern Africa, 12:557-578.

BEALL, J., GELB, S. \& HASSIM, S. 2005. Fragile stability: state and society in democratic South Africa. Journal of Southern African Studies, 31(4):681-700.

BHORAT, R. \& KANBUR, R. 2006. Introduction. Poverty and well-being in post-apartheid South Africa. In: BHORAT, H. \& KANBUR, K. (eds) Poverty and policy in Post-Apartheid South Africa. Cape Town: HSRC Press.

BUDGET SPEECH. 2007. Minister of Finance. Trevor Manuel, MP. 21 February.

CASE, A. \& DEATON, A.S. 1998. Large cash transfers to the elderly in South Africa. Economic Journal, 108(450):330-1361. 
CASE (COMMUNITY AGENCY FOR SOCIAL ENQUIRY). 1998. Social security for people with disabilities. Researched for the Department of Welfare. June. Johannesburg: CASE.

CASE (COMMUNITY AGENCY FOR SOCIAL ENQUIRY). 2000. Phasing in the Child Support Grant. A social impact study. Researched for the Department of Welfare. July. Johannesburg: CASE.

CASE (COMMUNITY AGENCY FOR SOCIAL ENQUIRY). 2005. Investigations into the increase in uptake of disability and care dependency grants since December 2001. Johannesburg: Case.

DEPARTMENT OF HEALTH. 2005. Report: National HIV and Syphilis Ante-Natal SeroPrevalence Survey in South Africa. Pretoria: Department of Health.

DEPARTMENT OF SOCIAL DEVELOPMENT. 2006. Annual Report. Pretoria.

DBSA (DEVELOPMENT BANK OF SOUTHERN AFRICA). 2005a. The employment of people with disabilities in South Africa. Compiled by the Employment Equity Unit. Paper No. 170.

DBSA (DEVELOPMENT BANK OF SOUTHERN AFRICA). 2005b. Development report. Overcoming underdevelopment in South Africa's second economy. July.

DBSA (Development Bank of Southern Africa). 2008. Inequality in South Africa: emerging issues. Draft Report 2007. ISSN 1997-8049.

ELLIOTT, D. 1993. Social work and social development towards an integrative model for social work practice. International Social Work, 36:21-36.

FEDDERKE, J. 2006. From chimera to prospect: South African sources of and constraints on long-term growth, 1970-2000. In: BHORAT, H. \& KANBUR, R. (eds) Poverty and policy in Post-Apartheid South Africa. Cape Town: Human Sciences Research Council: 18-58.

GRAY, M.M.A. 1997. A pragmatic approach to social development. Social Work/ Maatskaplike Werk, 33(3):210-233.

HASSIM, S. 2006. The women's movement in democratic South Africa. In: BALLARD, R., HABIB, A. \& VALODIA, I. (eds) Voices of protest, social movements in Post-Apartheid South Africa. Scottsville: University of KwaZulu-Natal Press: 349-370.

LESHILO, W. 2004. The feelings of people with physical disabilities regarding discrimination in Tembisa. Pretoria: University of Pretoria. (Unpublished MA Dissertation in Social Work (Health Care))

LOMBARD, A. 1996. Developmental social welfare in South Africa: a theoretical perspective. Social Work/Maatskaplike Werk, 32(2):162-172.

McCORD, A. 2004. Public works and overcoming under-development in South Africa. Conference on Overcoming Under-Development in South Africa's Second Economy. 29 October. UNDP. Human Sciences Research Council (HSRC) \& Development Bank of Southern Africa (DBSA).

MIDGLEY, J. 1995. Social development. The developmental perspective in social welfare. London: Sage Publications. 
MIDGLEY, J. 1997. Social welfare in a global context. Thousand Oaks, London, New Delhi: Sage Publications.

MOLLER, V. \& SOTSHONGAYE, A. 1996. My family eats this money too: pension sharing and self-respect among Zulu grandmothers. Southern African Journal of Gerontology, 5:919.

NATTRASS, N. 2006. Disability and welfare in South Africa's age of unemployment and AIDS. In: SOUTHALL, R. \& DANIEL, J. (eds) The State of the Nation, 2007. Pretoria: HSRC.

PADAYACHEE, V. 2005. The South African economy. Social Research, 72(3):549-580.

PAIVA, J.F.X. 1997. A conception of social development. Social Service Review, 51(2):327336.

PATEL, L. (ed) 2005. Social welfare and social development in South Africa. Cape Town: Oxford University Press Southern Africa.

RSA (REPUBLIC OF SOUTH AFRICA). 1996. The Constitution of the Republic of South Africa. Act 108 of 1996. Pretoria: Government Printers.

RSA (REPUBLIC OF SOUTH AFRICA). 1997. Ministry of Welfare and Population Development. White Paper for Social Welfare. Government Gazette. Vol. 386 (18166). August. Pretoria: Government Printer.

SAMSON, M., LEE., NDLEBE, A., MACQUENE, K., VAN NIEKERK, I., GANDHI, V., HARIGAYA, T. \& ABRAHAMS, C. 2004. Summary report. The social and economic impact of South Africa's social security system. Department of Social Development. 30 September.

SEEKINGS, J. \& NATTRASS, N. 2005. Class, race and inequality in South Africa. Scottsville: University of KwaZulu-Natal Press.

SEN, A. 1999. Development as freedom. Oxford: Oxford University Press.

SEIDMAN-MAKGETLA, N. 2004. Women and the economy. Paper prepared for the Genderstats project. Available: www.womensnet.org.za/genderstats/economy. [Accessed: 13/03/2006].

SOUTH AFRICAN INSTITUTE OF RACE RELATIONS (SAIRR). 2005. Fast facts: the poor get poorer. September. Johannesburg.

SPEECH FOR THE ACTING MINISTER OF HEALTH. 2007. Summit on Intergovernmental Relations. 3 May. Available: http://www.doh.gov.za/docs/sp2007/ sp0503.html. [Accessed: 20/06/2007].

STATSSA (STATISTICS SOUTH AFRICA). 2005. Labour Force Survey. P0210. September. Pretoria.

STEVENS, L. 2003. Chronic poverty in urban informal settlements in South Africa: combining quantitative and qualitative data to monitor the impact of interventions. Intermediate Technology Development Group. Warwickshire, UK: Schumacher Centre for Technology Department.

TAYLOR, V. 2002. The Committee of Inquiry into a comprehensive social security system. Transforming the present - protecting the future. Draft Report. 
TRIEGAARDT, J. \& PATEL, L. 2005. Social security. In: PATEL, L. (ed) Social welfare and social development in South Africa. Cape Town: Oxford University Press: 122-153.

UNDP (UNITED NATIONS DEVELOPMENT PROGRAMME). 2003. South African Human Development Report. The challenge of sustainable development: unlocking people's creativity. Cape Town: Oxford University Press.

UNDP (UNITED NATIONS DEVELOPMENT PROGRAMME). 2006. Human Development Reports. New York: Oxford University Press.

VAN DER BERG, S. \& BREDENKAMP, C. 2002. Devising social security interventions for maximum poverty impact. Social Dynamics, 28:39-68.

VAN DER BERG, S., BURGER, R., BURGER, R., LOUW, M. \& YU, D. 2005. Trends in poverty and inequality since the political transition. Bureau for Economic Research, Dept. of Economics. University of Stellenbosch. Stellenbosch Economic Working paper. 1/2005.

VASS, J. 2006. Women's unemployment: nature and impact. Title of Conference: Overcoming Unemployment. Giving effect to the "Right to Work Campaign". District Six Museum. 13 June.

Prof Jean D Triegaardt, Department of Social Work, University of Johannesburg, Johannesburg, South Africa. 